\title{
PENELUSURAN MISKONSEPSI DALAM PEMBELAJARAN TATA KALIMAT DENGAN PENDEKATAN KONSTRUKTIVISME BERBASIS INKUIRI PADA SISWA KELAS I SMP LABORATORIUM UNDIKSHA SINGARAJA
}

\author{
Ida Bagus Putrayasa \\ Jurusan Pendidikan Bahasa dan Sastra Indonesia \\ Fakultas Bahasa dan Seni \\ Universitas Pendidikan Ganesha, Singaraja, Indonesia
}

\begin{abstract}
Abstrak
Tujuan penelitian ini adalah menjawab permasalahan (1) miskonsepsi-miskonsepsi yang terdapat pada siswa tentang objek dan adverbial, (2) efektivitas strategi pengubahan konsepsi, (3) tingkat penguasaan siswa atas konsep-konsep objek dan adverbial, dan (4) komentar siswa tentang pendekatan konstruktivisme berbasis inkuiri dalam mempelajari konsep-konsep objek dan adverbial. Untuk mencapai tujuan tersebut, dirancang penelitian eksperimen dengan melibatkan dua kelas, yang masing-masing kelas dijadikan kelas eksperimen dan kelas kontrol. Pada tiap-tiap kelas diambil 22 siswa kelas VII SMP Lab Undiksha secara acak untuk dijadikan sampel. Data yang terkait dengan permasalahan di atas, dikumpulkan dengan tes dan kuesioner. Data yang terkumpul dianalisis secara deskriptif dan uji t. Hasilnya menunjukkan bahwa siswa yang diajar dengan pendekatan konstruktivisme berbasis inkuiri lebih baik daripada model konvensional dalam mempelajari konsep-konsep objek dan adverbial. Berdasarkan hasil tersebut, disarankan kepada guru agar menerapkan pendekatan tersebut sebagai salah satu alternatif dalam pembelajaran bahasa Indonesia (khususnya dalam kalimat).
\end{abstract}

Kata-kata kunci: konstruktivisme, inkuiri, objek, adverbial

\begin{abstract}
The aim of this study was to find out (1) the students' misconceptions about object and adverbial, (2) the effectiveness of conception modification strategy, (3) the students' mastery of concepts of object and adverbial, and (4) the students' comments about constructivism approach based inquiry in learning concepts of object and adverbial. For this purpose an experiment was conducted at two classes were selected from each of the class as experiment and control classes. Twenty two students of class VII SMP Lab Undiksha of each of the two classes were selected as sample through random sampling. The data concerning the above problems were collected by a test and questionnaire. The data were analyzed descriptively and t-test. The result demonstrated that the students who were taught with constructivism approach based inquiry could learn the concepts of object and adverbial better than those who were taught with conventional model. Based on the result it can be suggested to the teachers to implement the approach as one of the alternatives in the teaching and learning of Indonesian (particularly in the teaching and learning of sentences).
\end{abstract}

Key words: constructivism, inquiry, object, adverbial

\section{PENDAHULUAN}

Tujuan pembelajaran Bahasa Indonesia pada jenjang sekolah menengah adalah membekali peserta didik seperangkat pengetahuan (pemahaman konsep), kemampuan dan keterampilan menggunakan bahasa Indonesia, kemampuan intelektual (keterampilan berpikir), kematangan emosional, dan kematangan sosial agar dapat memahami lingkungan sekitar dan sebagai bekal melanjutkan pendidikan ke jenjang yang 
lebih tinggi (Kurikulum, 2004). Kenyataan yang terjadi di lapangan menunjukkan bahwa pembelajaran Bahasa Indonesia, khususnya pada jenjang sekolah menengah pertama masih dihadapkan pada masalah rendahnya mutu dan prestasi belajar yang dicapai oleh peserta didik.

Rendahnya mutu pendidikan dan prestasi belajar yang dicapai peserta didik dalam pembelajaran Bahasa Indonesia ditengarai banyak dikontribusi oleh model pembelajaran yang dianut dan diaplikasikan guru. Hal ini dipertegas lagi dengan seringnya guru menggunakan metode ceramah dalam pembelajarannya, sehingga peserta didik lebih banyak berposisi dan diposisikan sebagai objek pembelajaran.

Berdasarkan uraian di atas, tampaknya kita harus beralih pandangan dari pandangan konvensional ke pandangan inovatif, yakni pendekatan konstruktivisme yang lebih memposisikan pembelajaran pada upaya self-reconstruction, yaitu pengetahuan itu dibangun di dalam pikiran peserta didik dan oleh peserta didik itu sendiri dengan fasilitasi guru. Kalangan konstruktivist memandang bahwa pengetahuan itu pada dasarnya dibangun sendiri oleh peserta didik yang didasari oleh struktur kognitif yang telah ada dan dimiliki sebelum pembelajaran itu sendiri dilakukan (Fosnot, 1989). Sementara itu, guru lebih banyak berposisi sebagai mediator dan fasilitator kreatif selama berlangsungnya pembelajaran (Shymansky, 1992).

Yang menjadi masalah dalam penelitian ini adalah: (1) miskonsepsimiskonsepsi apakah yang terdapat pada siswa sehubungan dengan konsep objek dan adverbial? (2) bagaimanakah efektivitas strategi pengubahan konsepsi yang berupa konflik kognitif dalam mengubah miskonsepsi siswa dalam pembelajaran objek dan adverbial? (3) sejauh manakah tingkat penguasaan siswa atas konsepkonsep objek dan adverbial? dan (4) apakah pendekatan konstruktivisme berbasis inkuiri diterima siswa sebagai suatu kemudahan dalam mempelajari konsep-konsep objek dan adverbial?

Dalam kerangka konstruktivis, belajar dimaknai sebagai suatu upaya pengkonstruksian pengetahuan oleh individu sebagai pemberian makna atas data sensori yang berkaitan dengan pengetahuan yang telah ada sebelumnya (Tasker, 1992). Belajar merupakan suatu proses pemaknaan yang melibatkan konstruksikonstruksi dari para pembelajar (Sukadi, 1999; Sadia, 1996; Fosnot, 1989). Selanjutnya, Dyle dan Haas (1997) menyatakan bahwa belajar menurut pandangan konstruktivis lebih diarahkan pada terbentuknya makna pada diri pembelajar atas apa yang dipelajarinya berdasarkan pengetahuan dan pemahaman mereka sebelumnya.

Pembelajaran dengan inkuiri pada hakikatnya merupakan pembelajaran yang mempersiapkan situasi bagi anak untuk melakukan eksperimen sendiri; dalam arti luas ingin melihat apa yang terjadi, ingin melakukan sesuatu, ingin menggunakan simbul-simbul dan mencari jawaban atas pertanyaan sendiri, menghubungkan penemuan yang satu dengan penemuan yang lain, membandingkan apa yang ditemukan dengan yang ditemukan orang lain (Sund \& Trowbridge, 1973; Eltinge, 1993). Pendekatan konstruktivisme yang berbasis inkuri digunakan sebagai salah satu pendekatan pembelajaran untuk mengungkap miskonsepsi yang terjadi pada siswa. Miskonsepsi atau salah konsep menunjuk pada suatu konsep yang tidak sesuai dengan pengertian ilmiah atau pengertian yang diterima para pakar dalam bidang itu (Suparno, 2005).

Bentuk miskonsepsi dapat berupa konsep awal, kesalahan, hubungan yang tidak benar antara konsep-konsep, gagasan intuitif atau pandangan yang naif. Novak (1984) dalam Suparno (2005) mendefinisikan miskonsepsi sebagai suatu interpretasi konsep-konsep dalam suatu pernyataan yang tidak dapat diterima. Brown (1989) seperti yang dikutip oleh Suparno (2005) menjelaskan miskonsepsi 
sebagai suatu pandangan yang naif dan mendefinisikannya sebagai suatu gagasan yang tidak sesuai dengan pengertian ilmiah yang sekarang diterima. Miskonsepsi ini ditemukan juga dalam pemahaman tentang unsur-unsur pembentuk kalimat.

Kalimat merupakan untai kata yang mengandung pengertian lengkap. Untai kata ini bisa dibentuk dengan minimal dua kata atau lebih. Dua kata ini harus mengandung pengertian lengkap. Pengertian lengkap biasanya ditandai dengan adanya subjek dan predikat, dan bila dibalik susunannya (diinversikan) tidak mengubah pengertian kalimat semula.

Di samping $S$ dan $P$ sebagai unsur inti kalimat, terdapat juga unsur-unsur lain sebagai unsur tambahan kalimat, yaitu unsur objek, pelengkap, dan keterangan. Objek dan adverbial merupakan dua hal yang memiliki kemiripan karena posisi dan bentuknya berupa nomina. Kedua hal inilah yang sering menimbulkan miskonsepsi pada siswa. Karena itu, penelitian ini difokuskan pada kedua hal tersebut.

\section{METODE PENELITIAN}

Penelitian ini menggunakan rancangan penelitian eksperimen dengan pretest-posttest control group design. Dalam penelitian ini dilibatkan variabel perlakuan, yaitu pendekatan konstruktivisme berbasis inkuiri (X1) yang dikenakan pada kelas eksperimen, dan model belajar konvensional (X2) yang dikenakan pada kelas kontrol.

Penelitian ini dilakukan di Kelas VII

SMP Laboratorium Undiksha Singaraja.

yang terdiri atas tiga kelas. Dari ketiga kelas tersebut, dipilih dua kelas sebagai subjek penelitian, yang masing-masing diambil satu kelas sebagai kelas eksperimen dan satu kelas sebagai kelas kontrol. Penentuan kelas terpilih dilakukan dengan teknik random samling.

Prosedur yang ditempuh dalam penelitian ini meliputi tujuh tahapan sebagai berikut: (1) menggali, mengidentifikasi, dan menganalisis miskonsepsi-miskonsepsi yang terdapat pada siswa terkait dengan konsep objek dan adverbial. (2) merancang program pembelajaran serta menyusun strategi pengubahan konsepsi. (3) melatih guru yang akan ditugaskan untuk melaksanakan misi studi eksperimen ini. (4) mengimplementasikan program pembelajaran yang telah disusun pada tahap dua di atas. (5) mengevaluasi efektivitas pendekatan konstruktivis. (6) menganalaisis miskonsepsi siswa yang resistan. (7) merevisi strategi pengubahan konsepsi dengan memanfaatkan informasi yang diperoleh pada tahap keenam di atas.

Data penelitian ini dikumpulkan dengan tes, pedoman interviu, dan kuesioner. Data tentang pengetahuan awal siswa dideskripsikan secara naratif. Selanjutnya, untuk memperoleh gambaran tentang miskonsepsi-miskonsepsi yang terdapat pada siswa dan bagaimana perubahannya setelah proses pembelajaran, maka data yang diperoleh dari tes awal dan tes akhir dianalisis secara deskriptif dan penyimpulannya dinyatakan dengan persentase. Dari deskripsi tersebut, terlihat pula miskonsepsi-miskonsepsi mana yang bersifat resistan.

Data tentang pendapat siswa terhadap pendekatan konstruktivisme berbasis inkuiri, yang diperoleh melalui kuesioner dianalisis dengan statistik deskriptif dan penyimpulannya didasarkan atas skor rata-rata dan simpangan baku.

\section{HASIL PENELITIAN DAN PEMBAHASAN HASIL PENELITIAN}

Miskonsepsi-miskonsepsi yang terdapat pada siswa sehubungan dengan konsep (objek dan adverbial)

Miskonsepsi pada siswa menyangkut objek tampak pada semua siswa. Pada siswa yang tergolong KE, 69\% siswa mengatakan bahwa objek dibentuk oleh benda hidup, $56 \%$ siswa mengatakan dibentuk oleh orang, $60 \%$ siswa mengatakan objek terletak di tengah kalimat, dan $21 \%$ siswa mengatakan objek terletak di akhir kalimat. Sementara itu, 
pada siswa yang tergolong $\mathrm{KK}, 78 \%$ siswa mengatakan bahwa objek dibentuk oleh benda hidup dan $69 \%$ siswa mengatakan dibentuk oleh orang. Miskonsepsi pada siswa menyangkut adverbial kalimat juga tampak pada semua siswa. Pada siswa yang tergolong KE, 26\% siswa mengatakan bahwa adverbial dibentuk oleh benda mati; $65 \%$ siswa mengatakan dibentuk oleh benda hidup, 30\% siswa mengatakan dibentuk oleh bukan benda; dan $56 \%$ siswa mengatakan adverbial terletak di akhir kalimat. Sementara itu, pada siswa yang tergolong KK, 69\% siswa mengatakan bahwa adverbial dibentuk oleh benda hidup; $60 \%$ mengatakan adverbial dibentuk oleh orang; dan $17 \%$ mengatakan adverbial terletak di akhir kalimat. Miskonsepsi pada siswa menyangkut persamaan dan perbedaan objek dan adverbial kalimat juga tampak pada semua siswa. Pada siswa yang tergolong $\mathrm{KE}, 54 \%$ siswa mengatakan bahwa objek dan adverbial sama; sedangkan pada siswa yang tergolong KK, $43 \%$ siswa mengatakan bahwa objek dan adverbial sama.

Berdasarkan keadaan tersebut, dapat disimpulkan bahwa miskonsepsi terjadi pada siswa menyangkut unsur manasuka kalimat, khususnya objek dan adverbial kalimat. Semua siswa mempunyai konsep yang kurang akurat terhadap objek dan adverbial, baik menyangkut ciri-ciri maupun persamaan dan perbedaan keduanya. Siswa mempunyai konsep kurang lengkap dan bervariasi terhadap objek dan adverbial. Mereka secara dominan dan bervariasi mengatakan bahwa objek dibentuk oleh benda mati, benda hidup, orang, jenis kata benda, dan terletak di tengah kalimat. Siswa dominan dan bervariasi mengatakan bahwa adverbial dibentuk oleh orang, bukan orang, benda mati, benda hidup, terletak di tengah kalimat, dan di akhir kalimat. Sementara tentang persamaan dan perbedaan objek dan adverbial, secara dominan menyatakan bahwa objek dan adverbial sama dan ada yang mengatakan bahwa objek dan adverbial berbeda.

Adanya miskonsepsi yang terjadi pada siswa menyangkut unsur manasuka kalimat, khususnya objek dan adverbial kalimat tercenmin pula pada kemampuan mereka dalam memahami unsur manasuka kalimat, khususnya objek dan adverbial.

Sebagian besar kemampuan awal siswa tergolong kurang dalam hal memahami unsur manasuka kalimat, khususnya objek dan adverbial. Siswa yang kurang memahami objek dan adverbial $82 \%$, seperti tampak pada kelompok eksprerimen maupun kelompok kontrol.

Hasil interviu klinis yang dilakukan terhadap siswa menunjukkan bahwa keadaan itu terjadi karena pembelajaran yang diterapkan guru masih kurang memberi kesempatan mengemukakan pendapat dan berdialog, kurang membangkitkan minat, kurang memotivasi atau memberi semangat, kurang mengembangkan rasa ingin tahu dan kreativitas, kurang mengaktifkan, dan tidak memberikan kemudahan kepada siswa. Efektivitas Strategi Pengubahan Miskonsepsi menjadi Konsepsi yang Benar dalam Pembelajaran Unsur Manasuka Kalimat (Objek dan Adverbial).

Hasil penelitian yang dilakukan sebagaimana disampaikan sebelumnya menunjukkan bahwa miskonsepsi terjadi pada siswa menyangkut objek dan adverbial kalimat. Pada umumnya siswa mempunyai konsep yang kurang akurat terhadap objek dan adverbial, baik menyangkut ciri-ciri maupun persamaan dan perbedaan keduanya. Hasil interviu klinis yang dilakukan menunjukkan bahwa keadaan itu terjadi karena pembelajaran yang diterapkan guru masih kurang memberi kesempatan mengemukakan pendapat dan berdialog, kurang membangkitkan minat, kurang motivasi atau semangat, kurang mengembangkan rasa ingin tahu dan kreativitas, kurang mengaktifkan siswa, dan tidak memberikan kemudahan kepada siswa. Hal itu tercermin pada hasil kuesioner atau interviu klinis. 
Berdasarkan masalah yang dihadapi siswa yang tampak pada hasil interviu klinis, dilakukan penelitian eksperimen, yaitu merancang dan menerapkan pembelajaran unsur manasuka kalimat (objek dan adverbial) dengan pendekatan konstruktivisme berbasis inkuiri. Pendekatan pembelajaran tersebut pada intinya memberikan kesempatan kepada siswa untuk mengontruksi sendiri pengetahuannya tentang unsur manasuka kalimat (objek dan adverbial) dengan menyediakan data berupa kalimat-kalimat untuk diamati dan bereksperimen menemukan konsep bersupa ciri-ciri, pesamaan, dan perbedaan kedua hal itu denga cara berdiskusi, berbagi pendapat, dan bertanya kepada guru untuk menemukan jalan menarik kesimpulan jika mereka menghadapi jalan buntu.

Pendekatan pembelajaran unsur manasuka kalimat (objek dan adverbial) dengan pendekatan konstruktivisme berbasis inkuiri yang dimaksud direalisasikan dengan strategi pembelajaran yang tampak dalam kegiatan pembelajaran sebagai berikut: kegiatan pembuka: (1) mempersiapkan siswa dengan menciptakan suasana menyenangkan dan kondusif untuk belajar; (2) melakukan apersepsi yang terkait dengan unsur-unsur kalimat (3) menyampaikan tujuan pembelajaran; dan (4) membagi siswa dalam kelompok kecil dengan anggota 4 - 5 orang. Kegiatan inti (1) memberikan siswa lembar kerja siswa (LKS) yang berisi kalimat-kalimat yang sudah diperluas dengan objek yang dicetak tebal dan adverbial dicetak miring; (2) siswa diminta merumuskan ciri-ciri objek dan adverbial serta persamaan dan perbedaannya; (3) meminta siswa merumuskan ciri-ciri objek dan adverbial serta persamaan dan perbedaannya; (4) member kesempatan kepada siswa untuk bertanya; (5) siswa mewakili kelompok menyampaikan hasil kerjanya; (6) guru bersama siswa membahas hasil kerja masing-masing kelompok; (7) guru mengklarifikasi jawaban atau tanggapan sesuai dengan yang diharapkan siswa.
Kegiatan penutup: (1) merumuskan bersama siswa ciri-ciri objek dan adverbial serta perbedaan dan persamaannya; dan (2) melakukan evaluasi.

Hasil penelitian yang dilakukan menunjukkan bahwa strategi pengubahan miskonsepsi menjadi konsepsi yang benar dalam pembelajaran unsur manasuka kalimat (objek dan adverbial) yang berdasarkan pendekatan konstruktivisme berbasis inkuiri sebagaimana disampaikan tersebut tergolong efektif. Hal itu dapat dilihat pada kemampuan siswa dalam memahami unsur objek dan adverbial pada kelompok ekperimen dan kelompok kontrol serta hasil kuesioner yang dijawab siswa yang menjadi subjek penelitian.

Tingkat Penguasaan Siswa terhadap Unsur Manasuka Kalimat (Objek dan Adverbial Kalimat) dengan Menggunakan Pendekatan Konstrukti-visme Berbasis Inkuiri

Sebagaimana disampaikan pada bagian terdahulu, strategi pengubahan miskonsepsi menjadi konsepsi yang benar dalam pembelajaran unsur objek dan adverbial yang dikembangkan berdasarkan pendekatan konstruktivisme berbasis inkuiri tergolong efektif. Tingkat penguasaan siswa terhadap unsur objek dan adverbial kalimat dengan menggunakan pendekatan konstruktivisme berbasis inkuiri tergolong baik.

Sebagaimana hasil analisis data, skor rata-rata tes awal (T1) yang dicapai siswa yang tergolong $\mathrm{KE}$ dan $\mathrm{KK}$ adalah sama, yakni 53,25. Hal itu menunjukkan bahwa baik KE maupun KK dapat dikategorikan berkemampuan kurang dalam memahami konsep objek dan adverbial. Sementara itu, siswa yang tergolong dalam $\mathrm{KE}$ yang diperlakukan dengan menerapkan pendekatan konstruktivisme berbasis inkuiri mendapat nilai rata-rata tes akhir (T2) 90,25 yang berkategori sangat baik. KK yang diperlakukan dengan menerapkan pembelajaran konvensional mendapat skor rata-rata 55,65 yang berkategori cukup. Terhadap rerata hasil-hasil tes tersebut dilakukan analisis statistik, yaitu uji 
perbedaan dengan Uji-t untuk mendapatkan gambaran yang meyakinkan tentang hasil pengubahan miskonsepsi pada KE dan KK.

Hasil perhitungan terhadap perbedaan antara $\mathrm{T} 1$ dan $\mathrm{T} 2$ pada $\mathrm{KE}$ menunjukkan bahwa harga $t$ tabel untuk $\mathrm{db}$ 38 dalam taraf signifikansi $5 \%$ adalah 2.021 dan harga $t$ hitung yang didapat dari hasil penelitian adalah -2.123. Berarti $t$ hitung lebih besar daripada $t$ tabel, sehingga Ho ditolak dan $\mathrm{H} 1$ diterima. Hal itu berarti pula bahwa terdapat perbedaan penguasaan siswa terhadap unsur objek dan adverbial sebelum dan sesudah pendekatan pembelajaran konstruktivisme berbasis inkuiri dilakukan. Pada $\mathrm{KK}$, harga $t$ tabel untuk db 38 dalam taraf signifikansi 5\% adalah 2,021 dan harga $t$ hitung yang didapat dari hasil penelitian adalah $-0,182$. Berarti $t$ hitung lebih kecil daripada $t$ tabel, sehingga Ho diterima dan $\mathrm{H} 1$ ditolak. Hal itu berarti pula bahwa terdapat perbedaan penguasaan siswa terhadap unsur objek dan adverbial sebelum dan sesudah pembelajaran secara konvensional dilakukan.

Selanjutnya, hasil uji perbedaan dengan Uji-t terhadap T2 pada KE dan T2 pada KK memperlihatkan perbedaannya tidak signifikan. Secara statistik mempunyai korelasi sebesar 1,143 dan nilai $t$ hitung lebih kecil daripada $t$ tabel. Berdasarkan uji signifikansi tersebut, dapat disimpulkan bahwa prestasi belajar siswa tentang unsur objek dan adverbial yang menggunakan pendekatan konstruktivisme berbasis inkuiri lebih baik daripada prestasi belajar siswa yang menggunakan model pembelajaran konvensional. Penerapan Pendekatan Konstruktivisme sebagai Suatu Kemudahan dalam Mempelajari Unsur Manasuka Kalimat (Objek dan Adverbial)

Untuk memperoleh gambaran tentang komentar siswa terhadap pendekatan konstruktivisme yang berbasis inkuiri, data yang diperoleh melalui kuesioner dianalisis secara deskriptif. Dalam menarik kesimpulan, kriteria yang digunakan adalah pendapat siswa sebagai dasar penentuan kategori kualifikasi.

Dalam penelitian ini digunakan kuesioner sebanyak tujuh butir pertanyaan dengan masing-masing alternatif jawaban tiga butir. Dengan memperhatikan persentase jawaban siswa, dapat diperoleh gambaran tentang penerapan pendekatan konstruktivisme sebagai suatu kemudahan dalam mempelajari unsur manasuka kalimat (objek dan adverbial).

Berdasarkan hal itu, kemudahan bagi siswa dalam penerapan strategi pengubahan miskonsepsi menjadi konsepsi yang benar dalam pembelajaran unsur manasuka kalimat (objek dan adverbial) dikembangkan berdasarkan pendekatan konstruktivisme berbasis inkuiri.

\section{PEMBAHASAN}

Secara umum, pengetahuan awal siswa tentang objek dan adverbial mengalami miskonsepsi. Pada umumnya siswa mempunyai konsep yang kurang akurat terhadap objek dan adverbial, baik menyangkut ciri-ciri maupun perbedaan dan persamaan keduanya. Miskonsepsi siswa yang paling menonjol adalah bahwa objek kalimat hanya bisa dibentuk oleh orang, benda hidup, dan kelas kata benda. Jenis lain dan kelas katas yang lain tidak bisa menduduki objek tersebut. Hal ini sesuai dengan teori yang dikemukakan oleh Sutan Takdir Alisyahbana (1978) dan RobertBurton (1997) yang mengatakan bahwa objek adalah benda. Konsep inilah yang sangat melekat pada pikiran siswa, sehingga tidak ada yang lain bisa membentuk objek, selain benda itu sendiri. Demikian pula halnya dengan adverbial, bahwa dalam konsep siswa, adverbial tersebut hanya bisa dibentuk oleh benda hidup.

Miskonsepsi siswa tentang objek dan adverbial menurun ketika dalam pembelajaran diterapkan strategi pengubahan konsepsi dengan konflik kognitif. Hal ini sesuai dengan hasil penelitian yang dihasilkan oleh Sadia 
(1996), yang menunjukkan bahwa konflik kognitif dalam pembelajaran konsep-konsep IPA (energi, panas) dapat menurunkan miskonsepsi-miskonsepsi siswa. Sehubungan dengan penelitian yang dilakukan ini, dengan konflik kognitif, siswa diberikan konsep-konsep tentang objek dan adverbial dengan konsep yang benar. Konflik kognitif ini diberikan pada kelas eksperimen yang diperlakukan dengan menerapkan strategi pengubahan miskonsepsi menjadi konsepsi yang benar dalam pembelajaran unsur-unsur manasuka kalimat (objek dan adverbial), yang dikembangkan berdasarkan pendekatan konstruktivisme berbasis inkuiri. Sementara itu, pada kelas kontrol diperlakukan dengan menerapkan pembelajaran konvensional.

Dengan menerapkan strategi konflik kognitif, miskonsepsi-miskonsepsi siswa tentang objek dan adverbial menurun, yang tadinya miskonsepsi menjadi konsep ilmiah. Artinya, tingkat penguasaan siswa tentang konsep-konsep objek dan adverbial menjadi semakin baik. Dengan konflik kognitif ini pula, penerapan pendekatan konstruktivisme berbasis inkuiri menjadi efektif diterapkan dalam pembelajaran Bahasa Indonesia, khusunya yang menyangkut unusr-unsur manasuka kalimat (objek dan adverbial). Dengan efektifnya penerapan pendekatan konstruktivisme berbasis inkuiri dalam pembelajaran Bahasa Indonesia (khususnya objek dan adverbial) ini, siswa merasa senang dan berkomentar positif terhadap penerapan pendekatan tersebut. Penerapan pendekatan tersebut dapat memberikan kemudahan pada mereka dalam mempelajari konsep-konsep objek dan adverbial. Pengetahuan yang digali dan dikonstruksinya sendiri dengan aktif, kreatif, serta menggunakan logika, menjadi tahan lama bersemayam dalam otak atau pikirannya. Mereka juga dengan mudah mentransfer pengetahuan tersebut kepada orang lain atau teman-teman sejawatnya dalam mempelajari konsepkonsep kebahasaan.

\section{PENUTUP}

Berdasarkan uraian di atas, dapat dipaparkan hal-hal sebagai berikut. (1) Sebelum dilakukannya treatment terhadap kelas eksperimen ditemukan miskonsepsimiskonsepsi siswa tentang unsur objek dan adverbial. Namun, setelah dilakukan treatment, miskonsepsi siswa tentang unsur objek dan adverbial mengalami penurunan. (2) Strategi pengubahan konsepsi dengan konflik kognitif cukup efektif menurunkan miskonsepsi siswa tentang unsur objek dan adverbial. (3) Tingkat penguasaan siswa tentang objek dan adverbial yang diajarkan dengan pendekatan konstruktivisme berbasis inkuiri lebih baik daripada siswa yang diajarkan dengan model konvensional. (4) Komentar siswa terhadap penerapan pendekatan konstruktivisme berbasis inkuiri dalam pembelajaran unsur objek dan adverbial adalah positif. Berdasarkan simpulan tersebut, disarankan kepada pengajar bahasa Indonesia (khususnya konsep-konsep kalimat), agar menerapkan pendekatan konstruktivisme berbasis inkuiri sebagai salah satu alternatifnya.

\section{DAFTAR PUSTAKA}

Depdiknas. 2004. Kurikulum 2004. Jakarta: Depdiknas

Eltinge, E.M. 1993. Linguistic content analysis: a method to measure science as inquiry in textbooks dalam Jounal of Research in Science Teaching Vol.30 No.I PP. 65-83 (1993).

Fosnot, C.T. 1989. Equiring teachers equiring learners: a constructivist approach for teaching. New York: Teachers College Press.

Sadia, W. 1996. Pengembangan model belajar konstruktivis dalam pembelajaran IPA di Sekolah Menengah Pertama (SMP). Disertasi. PPS IKIP Bandung.

Shymansky, J.A. \& Keyle, W.C. 1992. Establishing a research agenda: 
critical issues of science curriculum reform. JRST. Vol.30, Issues 7.

Sund \& Trowbridge. 1973. Teaching science by inquiry in the scondary school. Columbus: Charles E. Merrill Publishing Comapany.
Suparno, P. 2005. Miskonsepsi dan perubahan konsep pendidikan fisika. Jakarta: PT Gramedia.

Tasker, R. 1992. Effective teaching: what can a constructivist view of learning offer? ASTJ. Vol.38, No.1. 